\title{
Sezaryen Skar gebeliği: İki olgu nedeniyle
}

\section{Cesarean scar pregnancy: Two case reports}

\section{Savaş Karakuş*, Çağlar Yıldız, Özlem Bozoklu Akkar, Meral Çetin}

Kadın Hastalıkları ve Doğum Anabilim Dalı (Yrd. Doç. S. Karakuş, Yrd. Doç. Ç. Yıldız, Yrd. Doç. Ö. B. Akkar, Prof. Dr. M. Çetin ), Cumhuriyet Üniversitesi Tıp Fakültesi, TR-58140 Sivas.

\section{Özet}

Sezaryen skar gebeliği konseptusun sezaryen skarındaki myometriyuma yerleşmesidir. Hayatı tehdit eden durum olup ektopik gebeliğin yanlıș tanısı, hastanın önemli oranda morbidite ve mortalitesine neden olabilir. Laparatomik veya laparoskopik trofoblastik doku çıkarılması, sistemik veya lokal metotreksat verilmesi, dilatasyon küretaj ve uterin arter embolizasyonu gibi birçok tedavi yaklaşımı vardır. Kliniğimize başvuran, iki sezaryen skar gebeliğinde farklı iki tedavi yöntemi olan histerotomiyle ve sistemik metotreksat la tedavisini ve sonuçlarını sunduk.

Anahtar sözcükler: Sezaryen skar gebeliği, ektopik gebelik, tedavi

\begin{abstract}
Caesarean scar pregnancy conceptus implants in the myometrium at the site of a cesarean section scar. It is potentially life-threatening condition. Misdiagnosis of ectopic pregnancy can result in significant patient morbidity and mortality. Many therapeutic options are available such as dilatation and curettage, local or systemically administered methotrexate, excision of trophoblastic tissues using either laparotomy or laparoscopy and uterine artery embolization. We showed to present a case of cesarean scar pregnancy that was managed by sistemik methotrexate and hysterotomy.
\end{abstract}

Keywords: Caesarean scar pregnancy, ectopic pregnancy, treatment

Geliş tarihi/Received: 06 Haziran 2014; Kabul tarihi/Accepted: 12 Aralık 2014

\section{*İletişim adresi:}

Dr. Savaş Karakuş, Kadın Hastalıkları ve Doğum Anabilim Dalı, Cumhuriyet Üniversitesi Tıp Fakültesi, TR-58140 Sivas. E-posta: karakussavas@yahoo.com

\section{Giriş}

Uterus alt segment kesisi ile yapılan sezaryen obstetride sık yapılan bir ameliyattır ve gün geçtikçe daha çok yapılmaya başlanmıştır. Sezaryen skarında ektopik gebelik (SSEG) alt segment kesi ile yapılan sezaryenlerin uzun süreli komplikasyonlarından biri olup insidans1 \%0,45'tir [1]. Bu durum erken tanınmaz ve tedavi edilmezse hayatı tehdit eden sorunlara yol açabilmektedir.

Sezaryen skar ektopik gebeliği, gebelik büyüdükçe kontrol altına alınamayan kanama ve uterus rüptürüne neden olarak histerektomi gerektirebilir. Ultrasonografi (USG), hastalığın tanısında ilk trimesterde önemli bir tanı aracıdır. Gebelik kesesi (GS) myometriyum dokusu ile mesane arasında izlenir [1, 2]. Hastanın başvuru şikâyetleri karın ağrısı ve/veya vajinal kanama olabileceği gibi asemptomatik olup rutin takip sırasında fark edilmiş olabilir. Skar gebeliğinin servikal, servikoistmik gebelikler ve inkomplet abortustan ayırıcı tanısının yapılması önemlidir.

MRG skar gebeliğinin kesin tanısını koydursa da tanıda primer olarak transvajinal USG kullanılır. Transvajinal USG'de aşağıdaki kriterlerle tanı konulur. 
Boş uterin kavite, endometriyum net olarak görülmeli, boş servikal kanal,uterusun sajital görüntüsünde, uterus ön duvarında, alt segmentle mesane arasında sezaryen skarına yerleşmiş GS görüntüsü, renkli Dopplerde trofoblastik aktivitenin görüntülenmesi kullanılmalıdır [3].

İki tip sezaryen skar ektopik gebeliği vardır. Birincisi yüzeyel yerleşimli olanında gebelik kesesi uterin skardadır. Gebelik kesesi uterus duvarına yüzeysel olarak implante olmuştur. İkincil derin yerleşimlide ise, implantasyon tam skarın içindedir ve uterin kaviteye uzanır ve implantasyon myometriyumun derin tabakasına dek uzanır.

$\mathrm{Bu}$ iki durumda tedavi seçenekleri planlanırken yüksek $\beta$-hCG düzeyi,fetusun yaşıyor olup olmadığ olan gebelere, dilatasyon küretaj, metotreksat ve histereskopik rezeksiyon düşünülürken,derin yerleşimli myometriuma uzanan hastalarda ise, histerektomi gerekebilmektedir [4].

Günümüzde laparatomi ya da laparoskopik olarak insizyon yerinden ektopik gebeliğin rezeksiyonu tercih edilmektedir. Tedavi şeklinin seçilmesi, hastadan hastaya değişiklik göstermektedir. Seçilecek tedavi yöntemi gebelik haftasına, semptomlara ve klinik tecrübeye göre değişmektedir.

Genel olarak 5. ve 6. haftalarda tanı almasına rağmen litaratürde 15 haftada tanı alan skar gebeliği mevcuttur. Gebelik haftası ilerledikçe spontan rüptür riski de artmaktadır [5].

Yapılmış çalışmaların sınırlı olması ve vaka sunumu şeklinde olması nedeni ile kesinlik kazanmamıştır.Bu yüzden birçok farklı tedavi yöntemi uygulanmaktadır. Seçilecek tedavi gebeliğin büyüklüğüne, hastanın semptomlarının şiddetine, $\beta$-hCG seviyesine ve hastanın tedavisini üstlenen hekimin tecrübesine bağlıdır. Erken tanı ve tedavi ciddi komplikasyonları önlemek açısından önemlidir.

Biz de, erken tanı konulan skar insizyon gebeliğinde iki farklı tedavi yaklaşımını literatür eşliğinde tartışmayı amaçladık.

\section{Olgu sunumu}

\section{olgu 1}

SB, 40 yaşında, G7P3 Y3A3. Son adet tarihine göre 8 haftalık gebeliği olan ve başka hastanede 6 haftalık gebe iken gebelik takibi için gittiği hekim haftasıyla uyumlu tek canlı embriyo olduğunu tespit etmiştir. Öyküsünde $3 \mathrm{kez}$ sezaryen ile doğum yaptığı başkaca bir sağlı sorunu olmadı̆̆ belirlenmiştir. Kliniğimize kasık ağrısı şikâyeti ile başvurmuştur. Yapılan pelvik muayenede uterus 8 haftalık gebelik cesametinde ve karın hassast. Ultrasonografide uterusta eski sezaryen skarında haftasıyla uyumlu canlı gebelik ve batında yaklaşı $300 \mathrm{cc}$ kan izlendi. Hemodinamisi stabil olan hastanın Hb: 12,6 idi. Hastanın akut karın hali de göz önüne alınarak uterus rüptürü şüphesiyle operasyona alınd.

Batında 200 cc kan mevcuttu. Uterin skar dokusunda gebelik alanı rezeke edildi. İnraoperatif bir komplikasyon olmadi.

\section{Olgu 2}

EK, 28 yaşında, G3P1Y1A1. Beş haftalık gebeliği olan hasta kontrole gittiği zaman gebeliğinin skar insizyon düşünülerek bir başka hastaneden kliniğimize sevk edilmiştir. Öyküsünde bir kez sezaryenle doğum yaptığı öğrenildi. Yapılan ultrasonografik incelemede sezaryen skarında servikal internal osa $8 \mathrm{~mm}$ uzaklıkta 5 hafta ile uyumlu CRL: 3 mm FKA (+) gebelik kesesi izlendi. Douglasta serbest sivı izlenmedi. Hastaya rescue protokolü uygulandı. İlk ölçülen $\beta$-hCG 9742 idi. Hastanın hemodinamisinin stabil olması nedeniyle metotreksat protokolü uygulandı. 
Tablo 1. B HCG değerinin tedavi sonrası.

\begin{tabular}{ll}
\hline Tarih & $\boldsymbol{\beta}$-hCG \\
\hline 16.01.2014 & $14.306 \mathrm{mIU} / \mathrm{mL}$ \\
22.01. 2014 & $19.256 \mathrm{mIU} / \mathrm{mL}$ \\
28. 01. 2014 & $16321 \mathrm{mIU} / \mathrm{mL}$ \\
07. 02. 2014 & $3376 \mathrm{mIU} / \mathrm{mL}$ \\
21. 02. 2014 & $722 \mathrm{mIU} / \mathrm{mL}$ \\
24. 03. 2014 & $8,9 \mathrm{mIU} / \mathrm{mL}$ \\
01. 04. 2014 & $0.1 \mathrm{mIU} / \mathrm{mL}$ \\
11.04.2014 & $0.1 \mathrm{mIU} / \mathrm{mL}$ \\
25.04.2014 & $0.1 \mathrm{mIU} / \mathrm{mL}$ \\
\hline
\end{tabular}

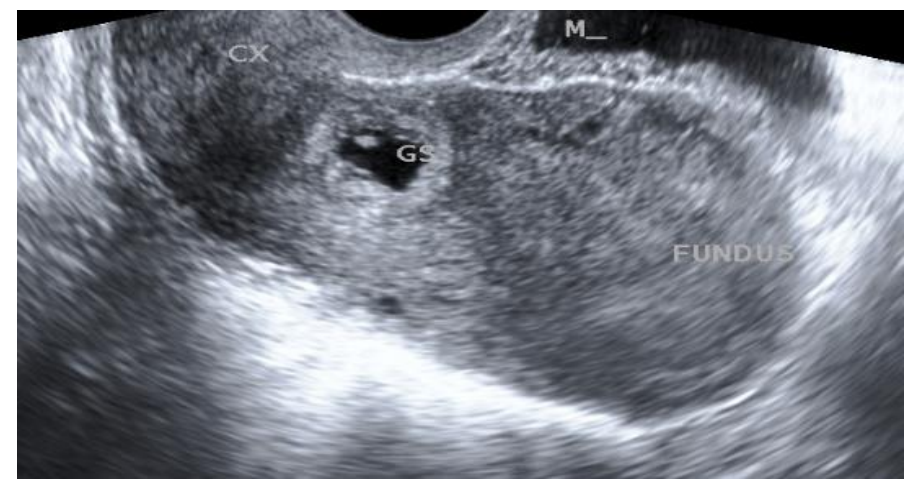

Resim 1. Skar insizyon gebeliğinin transvajinal ultrasonografi ile görüntüsü.

\section{Tartışma}

Sezaryen skarına ektopik gebeliğin implantasyonu nadir görülen bir durum olup yüksek morbidite ve mortalite ile seyreder. Sezaryen skar gebeliği artan sezaryen oranları nedeniyle artan oranlarda görülse de, ektopik gebeliğin en nadir görülen ve hayatı tehdit eden formlarından biridir. Eski kesi hattındaki defektif miyometriyuma trofoblast invazyonu nedeniyle ilerleyen gebelik haftasıyla birlikte, uterin ön duvar alt segmentinde artan anormal vaskülarizasyon ve varikozite kaçınılmazdır [6, 7].

Sezaryen oranlarının giderek artması ve yüksek çözünürlüklü USG cihazlarının kullanılması ile sezaryen skar gebeliği görülme ve tanı alma oranı artmıştır. Erken tanı konulmaz ise maternal ölüm görülebilmektedir. Risk faktörleri arasına geçirilmiş sezaryen öyküsü, myomektomi, D/C, histeroskopi gibi uterusta skara neden olabilecek işlemler yer almaktadır [8].

Nejković ve ark. [9] 36 yaşında IVF sonrası sezaryen skar ektopik gebeliği olan bir hastaya ultrasonografi eşliğinde $50 \mathrm{mg}$ intrasakkuler methotrexate lokal uygulamışlardır. Gebelik canlılı̆̆ını yitirdiğinde dokuyu D/C yaparak aspire etmişlerdir. Yela ve ark. [10] 28 yaşında bir sezaryen skar gebeliğini metotreksat, uterin arter embolizasyonu ve küretajla tedavi etmişler ve hastanın fertilitesini korumuşlardır.

Ülkemizden yazılan bir vaka takdiminde iki kez sezaryen geçirmiş bir hastada skar ektopik gebeliğine düşük doz metotreksat verilmiş, başarısız olunca yüksek doz metotreksat ve uterin arter embolizasyon uygulanarak tedavi edilmiştir [11].

Aras ve ark. [12] sezaryen skar gebeliği olan bir olguya iki doz metotreksat uyguladıktan sonra başarısız olmuşlar ve cerrahi tedavi uygulamışlardır.

Wang ve ark. [13] $\beta$-hCG değeri >5000 IU/mL ve kardiyak aktivitesi olan sezaryen skar gebeliği kadınlarda tedavi için uzun dönem ve yüksek miktarda metotreksat terapisi ya da 
lokal metotreksat tedavisi ile birleştirilmiş IV metotreksat terapisi gerekmesine rağmen, tek doz $100 \mathrm{mg}$ IV metotreksat ya da multidoz IV metotreksat $(20 \mathrm{mg}$, günde birkez beş doz) tedavisinin $\beta$-hCG değerinin $<5000 \mathrm{IU} / \mathrm{mL}$ ve fetal kardiyak aktivitenin olmadığı böyle hastalarda embriyosid etkili olduğunu göstermişlerdir.

Arıkan ve ark. [14] öyküsünde bir sezaryen bulunan ve $\beta$-hCG değeri $26905 \mathrm{mIU} / \mathrm{mL}$ olan 6 haftalık SSEG tanısını koydukları bir hastada başlangıçta uygulanan tek doz sistemik metotreksat tedavisi etkili olmadığı için metotreksat $(60 \mathrm{mg})$ dozu tekrarlamışlardır. Takipte gestasyonal kesenin boyutları büyümeye devam etmesi ve hasta karın ağrısı hissetmeye başlaması nedeniyle, ultrason eşliğinde dilatasyon ve küretaj işlemi uygulamışlardır.

Tedavisinde kesin bir görüş birliğine varılmamakla birlikte lokal veya sistemik metotreksat, bekleme tedavisi, dilatasyon ve küretaj, histeroskopi, lokal potasyum klorür enjeksiyonu, uterin arter embolizasyonu, myometriyal wedge rezeksiyonu ve histerektomi kullanılan tedavi yöntemleridir. Bu kadar farklı tedavi yaklaşımı olan nadir olarak görülen erken tanı konması ve doktorun tecrübesine göre hemen tedaviye başlanması hasta hayatı için önemlidir. Çok farklı farklı tedavi yaklaşımları olan, skar insizyonu ektopik gebeliğinde, hastaların klinik ve vital bulgularını göz önüne alarak iki vakada farklı iki yaklaşımı literatür eşliğinde tartışmak istedik.

\section{Kaynaklar}

1. Seow KM, Huang LW, Lin YM, Yan-Sheng Lin YL, Tsai, Hwang JL. Caesarean scar pregnancy: Issues in management Ultrasound Obstet Gynecol 2004; 23: 247 53.

2. Polat I, Alkis A, Sahbaz O, Sahin A, Ekiz B, Gulac. Diagnosis and management of cesarean scar pregnancy Clin Exp Obstet Gynecol 2012; 39: 365-8.

3. Maymon R, Halperin R, Mendlovic S, Schneider D, and Herman A, "Ectopic pregnancies in a caesarean scar: Review of the medical approach to an iatrogenic complication," Human Reproduction 2004; 10: 515-23.

4. Kucera E, Krepelka P, Krofta L, Feyereisl J. Cesarean scar ectopic pregnancy. Ceska Gynekol 2007: 72; 207-13.

5. Smith A, Ash A, Maxwell D. Sonographic diagnosis of cesarean scar pregnancy at 16 weeks. J Clin Ultrasound 2007; 35: 212-5.

6. Fylstra DL. Ectopic pregnancy within a cesarean scar: A review. Obstet Gynecol Surv 2002; 57: 537-43.

7. Jurkovic D, Hillaby K, Woelfer B. First-trimester diagnosis and management of pregnancies implanted into the lower uterine segment Cesarean section scar. Ultrasound Obstet Gynecol 2003; 21: 220-7.

8. Sadeghi H, Rutherford T, Rackow BW. Cesarean scar ectopic pregnancy: Case series and review of the literature. Am J Perinatol. 2010; 27: 111-120.

9. Nejkovic L, Pazin V, Filimonovic D.Cesarean section scar pregnancy treatment-case report. Clin Exp Obstet Gynecol 2013; 40: 304-6.

10. Yela DA, Marchiani N. Conservative management of ectopic pregnancy in cesarean scar: Case report. Rev Bras Ginecol Obstet 2013; 35: 233-7.

11. Büyükkurt S,Aksungur E,Vardar MA, Güzel AB, Güleç Ü Kadayıf̧ı O.Sezaryen Skar Yerinde Gelişen Dış Gebeliğin Konservatif Tedavisi Turkiye Klinikleri J Gynecol Obst 2010; 20: 133-7.

12. Aras Ö, Yüksel MA, Ateşer G, Boran AM. Sezaryen Skar Gebeliği: Nadir Görülen Bir Ektopik Gebelik, Olgu Sunumu. İstanbul Tip Derg Istanbul Med J 2011; 12: 135-8.

13. Wang $\mathrm{JH}, \mathrm{Xu} \mathrm{KH}$, Lin J. Methotrexate therapy for cesarean section scar pregnancy with and without suction curettage. Fertil Steril 2009; 92: 1208-13.

14. Arıkan DC, Turgut E. Kıran G, Kıran H. Metotreksat ve dilatasyon-küretaj ile tedavi edilen sezaryen skar gebeliği: Olgu sunumu. Dicle Tıp Dergisi 2012; 39: $102-4$. 